\title{
DESIGN AND MODIFICATION OF BALE CUTTING MACHINE TO IMPROVE ITS PRODUCTIVITY
}

\author{
Girish Kumar S.M ${ }^{1}$, V. Venkata Ramana ${ }^{2}$ \\ ${ }^{1} P G$ Student, Department of mechanical engineering, BITM, Bellay, Karnataka, India \\ ${ }^{2}$ Professor, Department of mechanical engineering, BITM, Bellay, Karnataka, India
}

\begin{abstract}
The aim of this paper is to present the results of the successful implementation of the redesigned bale cutting machine in Falcon tyre manufacturing company. Modification of hydraulic bale cutting machine is carried out to increase the productivity of the machine, to reduce the time and stress on the workers. The system is consisting of modified shear blade, suitable blade holder, hydraulic system according to new tonnage capacity and conveyor system. Unigraphics is used to model the blade and blade holder, meshing and analysis is carried out by using hypermesh and nastran. The parts are manufactured accordingly to new design parameters, and the following are installed and the performance characteristics to be determined are time, cost and productivity for this new modified design relative to the old system. It is established from the test results taken for a period of three months, that there is reduction in the time and cost of 70-80\%, and 50-60\% which in directly increased the productivity of machine and making the process economical.
\end{abstract}

Keywords: shear blade, blade holder, hydraulic system, conveyor system $* * *$

\section{INTRODUCTION}

A tyre is a ring shaped wrap that fits over the wheel's rim to secure it and to validate better vehicle performance". It is built upon a strong inner carcass with metal hoops embedded in it where it sits on the rim. Rubber is the basic raw material used in the production of tyres, the rubber in form of both natural and synthetic types are used along with some additives, tyres are manufactured according to standardized processes like mixing, extrusion, calandering, bead winding, bias cutting, tyre building ,raw cover painting, hauling, tyre curing, trimming, and inspection. Before being adding the rubber to the mixer it is needed to cut into small required sizes on a bale cutter machine. The bale cutting machine comprises of various parts shear blade, blade holder, main frame, table, arm, cylinder, and hydraulic system. The cutting of bale takes place when blade attached to the ram moves vertically downwards and shears the rubber placed on the table.

I. A. Daniyan, A. O. Adeodu and O. M, Dada from department of mechanical and mechatronics engineering worked on the design of conveyor system for the crushed lime stone using three roll idlers. They designed the material handling system in such a way that the process mist go cheaper providing supportive role to obtain good economical results, they worked on the system design which comprises the calculation for the values of roller diameter, belt length, belt thickness, belt inclination, spacing for idlers, mode of control, tension and power required, loading capacity of the conveyor system etc.

Shubham D Vaidya, Akash R samrutwar carried out their work on design of material handling system for an crushed biomass wood using $\mathrm{v}$ merge conveyor system, the project was comprising of designing and deriving the new values for various parameter in conveyor system as like belt diameter, belt thickness, belt inclination, and various all other parameters required to design the conveyor system was found out

Extractions from literature survey of conveyor system it shows that for designing of conveyor system various parameters needed to be finding out like belt length, inclination, belt capacity, roller diameter etc.

The objective of paper is to increase the productivity of bale cutting machine and to improve the easiness in material handling. In order to increase the productivity, the machinery is needed to modify and the necessary parts of it has to be redesigned, fabricating and installing those to the machine. As per the new required tonnage capacities to cut the maximum number of bales the supportive hydraulic system is needed to designed.

Designing of the blade involves finding out the new parameters rake angle, and shear angle. To hold the blade the suitable blade holder is needed to be designed with particular shape and dimensions, where as designing of hydraulic system is needed to select the suitable hydraulic equipments like hydraulic cylinder, control valves, pump, filters, type of oil used etc.

\subsection{Specification and Productivity of Bale Cutting}

\section{Machine (Before Modification)}

The hydraulic machine in the industry was installed few years back it works on the hydraulic energy and the necessary hydraulic power is supplied by the hydraulic 
system, the rubber bale is cut when the ram moves down and the blade fixed to that pierces it, the loading and unloading is done manually and it is tedious and the productivity of machine is not up to the mark as it is having the capacity to cut only one number of rubber bale which is resulting in low production rates.

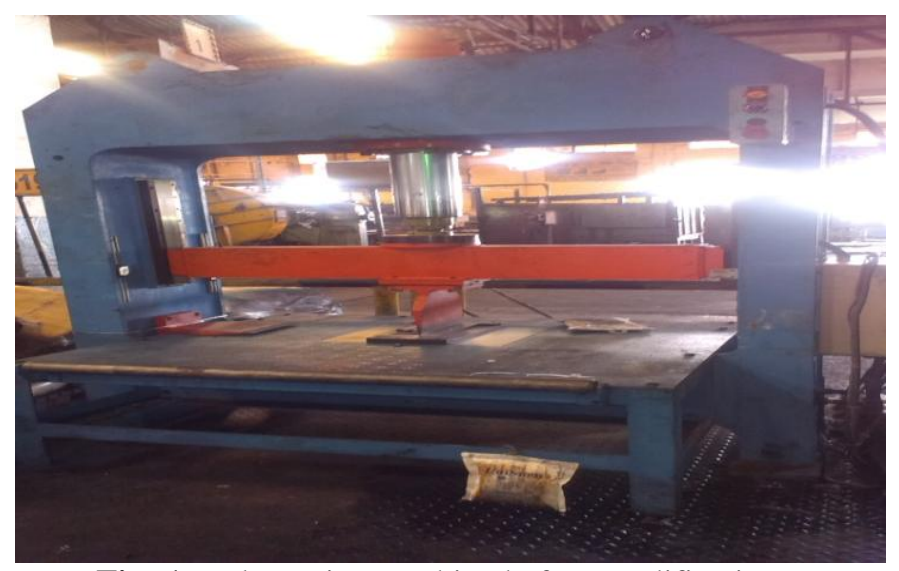

Fig -1: Bale cutting machine before modification

Table -1: specification of bale cutting machine

\begin{tabular}{|l|l|}
\hline Make & Germany \\
\hline Cutting stroke & $500 \mathrm{~mm}$ \\
\hline Diameter of cylinder & $150 \mathrm{~mm}$ \\
\hline Cylinder pressure & $150 \mathrm{~kg} / \mathrm{sq} \mathrm{cm}$ \\
\hline Blade width / stock thickness & $400 \mathrm{~mm} / 150 \mathrm{~mm}$ \\
\hline Time of cutting stroke & $12 \mathrm{~seconds}$ \\
\hline Motor power & $15 \mathrm{hp}$ \\
\hline Number of bales cut per stroke & $1 \mathrm{no}$ 's \\
\hline
\end{tabular}

The productivity of machine is too less the actual rubber required for the day plan is 120 tones and to cut the 120 tons of rubber the time required is 24.08 hours but after removing the unproductive time in a day(food, shift change, intervals) is 2.75 hours, after removing the unproductive time from day schedule the working of machine is carried out for only 21.25 hours and the achieved cutting of rubber is only about 109.62 tons the remaining 10.38 tons on rubber is remained uncut.

\section{DESIGN}

The following are the parts identified for modification 1. Design of blade and blade holder.

2. Design of hydraulic system.

3. Design of conveyor system.

\subsection{Design of Blade and Blade Holder}

The design of blade involves finding out the new rake and shear angle of the blade.

Shearing is a mass separating process which involves cutting of various cross sections without formation of chips. In this process, a portion of work-piece is separated from the rest. The shearing process is used as a preliminary step in preparing stock for various other processes.
During shearing, the work piece, i.e. the rubber bale, is placed between the movable blade and the work table. As the blade is forced down, the rubber bale is penetrated to a specific portion of the thickness and starts to separate. Finally, as the rubber bale is completely penetrated, the bale is separated into two halves. This is caused due to the highly localized shear stresses that the material experiences.

The shearing force required to cut the rubber bale is as follows

$$
\mathrm{Fs}=\frac{\mathrm{S} \times \mathrm{P} \times \mathrm{T}^{2}}{\mathrm{R}} \times(1-\underline{\mathrm{P}})
$$

Where,

Fs = Shearing force $\left(350 \times 10^{3} \mathrm{~N}\right)$

$\mathrm{S}=$ Shear strength of rubber $(50 \mathrm{MPa})$

$\mathrm{T}=$ Stock thickness $(250 \mathrm{~mm})$

$\mathrm{R}=$ Blade rake angle (degree)

$\mathrm{P}=$ Penetration of blade into material T (range: 0 to 1 )

$\mathrm{R}=5.6^{0}$

Thus, the shear angle is $\beta=75^{\circ}+\mathrm{R} / 2$

$\beta=77.8^{0}$

The total length of the blade is $1000 \mathrm{~mm}$ as it was the maximum possible dimension that could be given and its height is (T) $280 \mathrm{~mm}$ as it must be capable of cutting two rows of rubber bales (each of height $110 \mathrm{~mm}$ ) stacked one over the other. The thickness of the blade is assumed to be $30 \mathrm{~mm}$. Also, it is given taper of 1:14. This helps in easy retrieval of the blade during the return stroke.

The material of the blade selected is HCHC (high carbon high chromium). It is a cold working tool, provides good wear resistance and has moderate hardness. It is the most commonly used blade material. It is subjected to fracturing or chipping when shearing harder metals or heavier gauges as the material cut is rubber so the fracturing of blade is not a matter of worrying.

The blade is joined by five M12 bolts to the blade holder. The number of bolts and the type of bolt to be used is obtained as follows:

Density of HCC steel $=7.7 \times 1000 \mathrm{~kg} / \mathrm{m}^{3}$

Blade Weight $\mathrm{p}_{2}=48.972 \mathrm{~kg}=480.42 \mathrm{~N}$

From design data handbook, for an ordinary joint, initial bolt tension,

$$
\mathrm{p}_{1}=2805 * \mathrm{~d} \text { in } \mathrm{N}
$$

Where,

$\mathrm{d}=$ bolt diameter $(\mathrm{mm})$, assuming $\mathrm{d}=12 \mathrm{~mm}$

$\mathrm{p}_{1}=33660 \mathrm{~N}$

Thus total load $\mathrm{F}=\mathrm{p}_{1}+\mathrm{p}_{2}$ in $\mathrm{N}$

$\mathrm{F}=34140.42 \mathrm{~N}$ 
Tensile strength of bolt $=400 \mathrm{MPa}$

With a factor of safety of 4 , allowable working strength is $100 \mathrm{MPa}$.

Therefore, we have $100=\mathrm{F} /(\mathrm{N} \times \mathrm{A})$

Where,

$\mathrm{F}=\operatorname{Load}(\mathrm{N})$

$\mathrm{N}=$ Number of bolts

$\mathrm{A}=$ Load cross sectional area in $\mathrm{mm}^{2}$ (113.09)

$\mathrm{N}=3.1$

From data hand book the number of bolts selected is five

Thus, five number bolts have been proposed based on calculations of number of bolts. Based on the strength required, coarse grade M12 bolts have been proposed

To mount the blade on to the bale cutting machine, two blade holding devices were proposed and are as shown in the assembly of blade and blade holder figure below

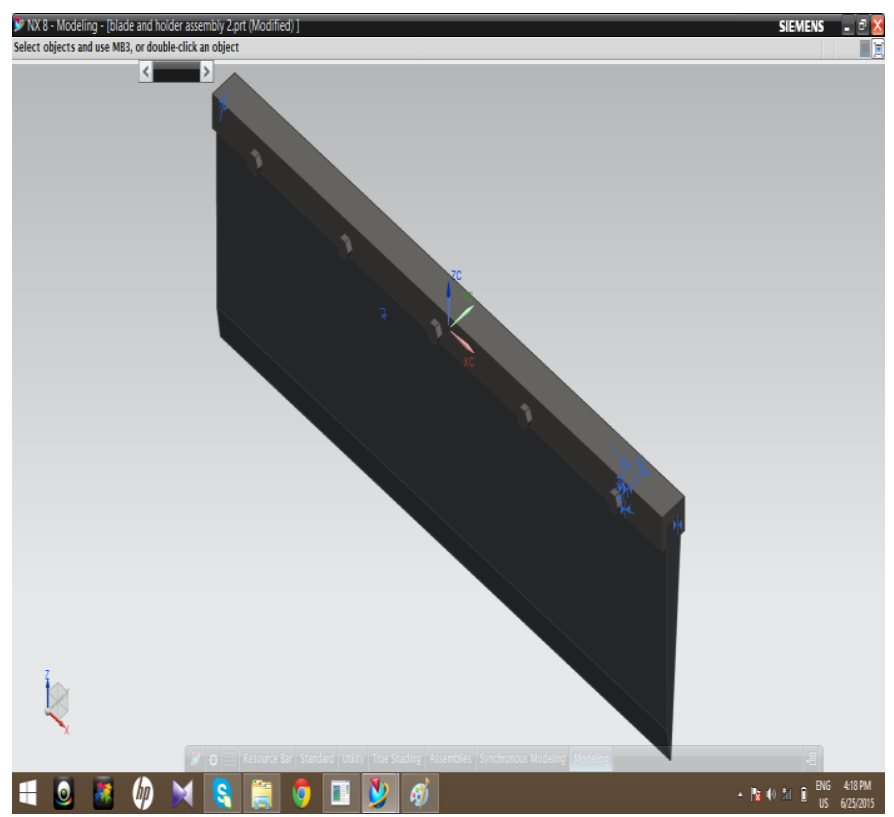

Fig -2: Blade and Blade holder assembly 1

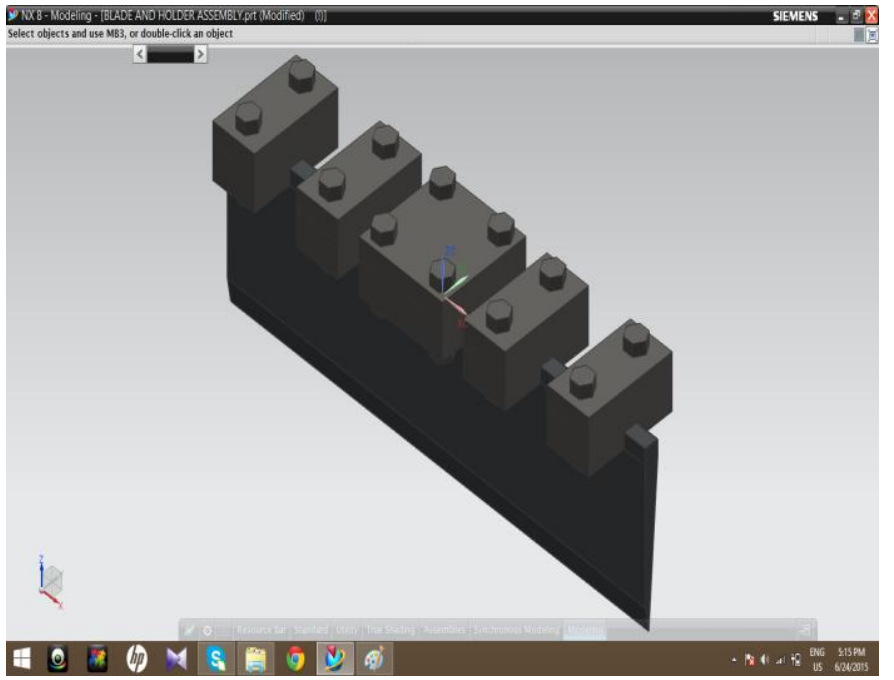

Fig -3: Blade and Blade holder assembly 2

Based on the pragmatics shown in table, design 2 was finalized. This design fulfilled the basic requirement, i.e. it constrains the blade movement in all directions. Also, the bolt life was highest in this design hence this leads to lesser machine down time.

Table -2: pragmatic analysis of proposed designs

\begin{tabular}{|l|l|l|}
\hline Parameter & Design 1 & Design 2 \\
\hline Fabrication ease & Easy & Difficult \\
\hline Cost & Moderate & Moderate \\
\hline DOF constrained & 6 & 6 \\
\hline Bolt life & Minimum & Maximum \\
\hline Material wastage & High & Moderate \\
\hline Reliability & Low & High \\
\hline $\begin{array}{l}\text { Displacement } \\
\text { variation }\end{array}$ & Minimum & Minimum \\
\hline \begin{tabular}{l} 
Stress variation \\
\hline
\end{tabular} & Minimum & Minimum \\
\hline
\end{tabular}

The raw material used for the fabrication of blade holder is forged Mild Steel with rectangular cross section. Mild Steel is one of the most commonly used metals and one of the least expensive steels used. It is weld-able, durable and hard, easily annealed. Various processes like gas cutting, lathe, shaping, drilling, tapping, grinding etc were carried out on the raw material to obtain the required dimensions.

The fabrication cost of blade and blade holder is rupees 47,160 . 


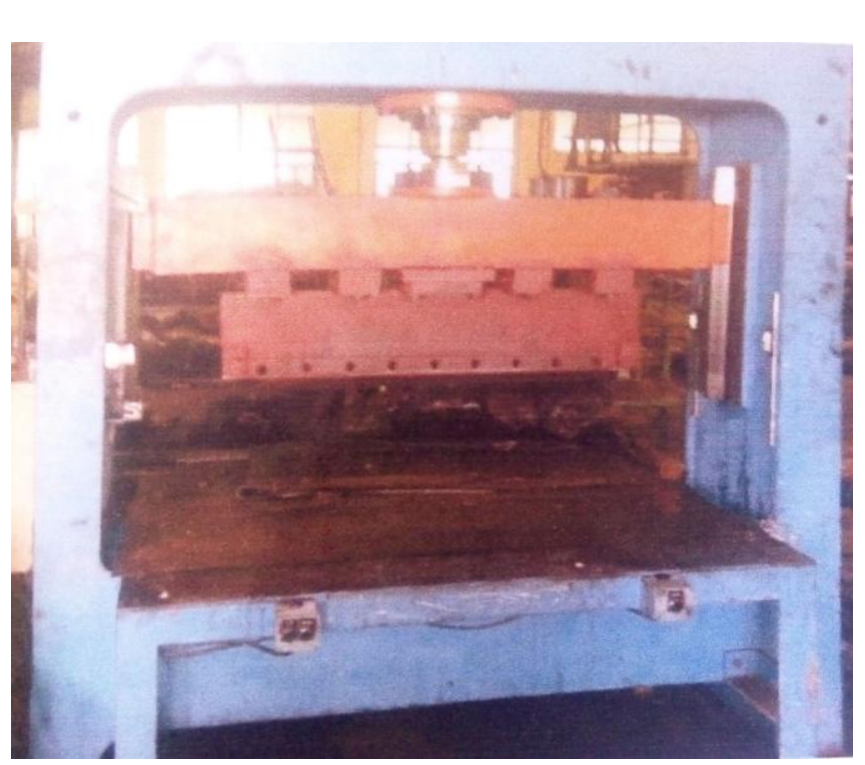

Fig -4: Bale cutting machine after modification

\subsection{Design of Hydraulic System}

Practical experiments were conducted on the existing bale cutting machine and it was determined that an average of $200 \mathrm{~kg} / \mathrm{cm}^{2}$ or 196.2 bars of pressure was required to shear rubber bales piled over each other.

Based on the pressure required to be developed to shear the rubber bales, from the catalogues of Bosch Rexroth, a standard cylinder was selected.

Standard cylinder: CD210 RE17017 (Tie rod type)

Nominal pressure $=210$ bar

Piston diameter $=150 \mathrm{~mm}$ (range from 14-200 mm)

Piston rod diameter $=30 \mathrm{~mm}$ (range from $16-140 \mathrm{~mm}$ )

Maximum stroke length $=3000 \mathrm{~mm}$

(We require a stroke length of $500 \mathrm{~mm}$ )

Maximum stroke speed $=0.5 \mathrm{~m} / \mathrm{s}$

Thus, the average cutting force from the cylinder required to shear the rubber bales piled over each other $(\mathrm{Fc})$ in $\mathrm{kN}$

$$
F_{c}=\text { Pressure required to shear } \times \text { Piston area }
$$

Where,

Piston area $=\pi \mathrm{r}^{2}$ in $\mathrm{m}^{2}$

$\mathrm{F}_{\mathrm{c}}=\mathbf{3 4 6 . 7 1 4 \mathrm { KN }}$

Quantity of cylinder oil required for a stroke of $500 \mathrm{~mm}$ $=$ Cylinder effective area $\times$ cylinder stroke in $\mathrm{m}^{3}$

Where,

Cylinder effective area $=\pi \mathrm{r}^{2}$ in $\mathrm{m}^{2}$ (diameter of cylinder $150 \mathrm{~mm})$

Quantity of cylinder oil required $=\mathbf{8 . 8 3 5} \times \mathbf{1 0}^{-3} \mathbf{m}^{\mathbf{3}}$ or liter The type of oil used in hydraulic cylinder is ISO 68 (SAE $20 \mathrm{~W})$, density $865 \mathrm{~kg} / \mathrm{m}^{3}$
From the manual of Bosch Rexroth, a suitable variable displacement pump is selected which would efficiently aid in producing required pressure without any hesitation.

Type: A10VSO (Variable displacement pump)

Size: 10

Nominal pressure: 250 bar

Peak pressure: $315^{\text {ba2r }}$

Displacement: $10 \mathrm{~cm}^{3}$

Speed: 3600 RPM

Flow@ max speed: 37.8 liter/min

Power@280 bar=15.7 KW

Maximum toque $=41.7 \mathrm{Nm}$

A standard motor was chosen along with this pump from the Bosch Rexroth manual. This motor provides a peak power of $15.7 \mathrm{KW}$ (21 Hp).

\section{Counter balance pressure $=\underline{\text { Net pressure acting on } \operatorname{ram} \times \mathrm{g}}$} Effective area of the piston

Where,

Net pressure acting on ram in $\mathrm{kg} / \mathrm{cm}^{3}$ $\mathrm{g}=$ acceleration due to gravity in $\mathrm{m} / \mathrm{sec}^{2}$ Effective area of piston $=0.0054 \mathrm{~m}^{2}$

Counter balance pressure $=1.16$ bar

Since, the acting force on the ram is enormous, a factor of safety of 10 is considered for the counter balance pressure. Thus, a counter balance pressure of 12 bar is applied.

The proposed hydraulic circuit is shown in the figure 4.5. The circuit consists of various hydraulic components, namely, double acting hydraulic cylinder, counter balance valve (counter balance pressure $=12$ bar), fixed displacement pump, 4/3 manually actuated spring centered open centered valve, filter, check valve and pressure relief valve (relief pressure $=200 \mathrm{bar}$ ).

The cost of hydraulic equipments and installation is rupees 69,180 .

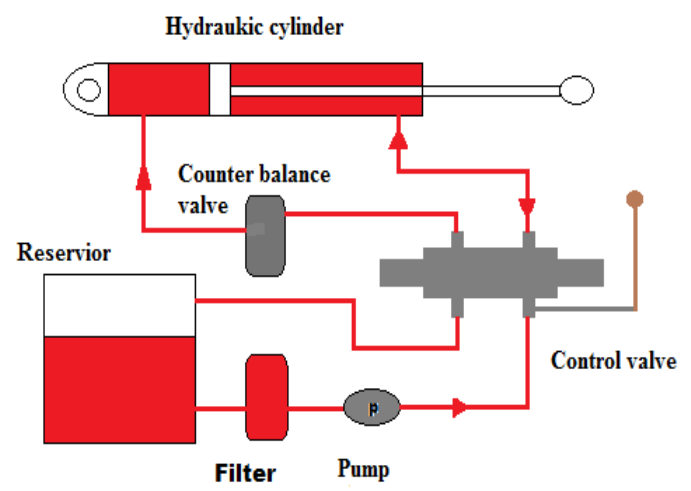

Fig -5: Designed hydraulic circuit 


\subsection{Design of conveyor system}

The belt conveyor system is found to be well suited for the available floor space. The design of belt conveyor system involves determination of the correct dimension of the belt conveyor components and other critical parameter values so as to ensure optimum efficiency during loading and unloading conditions. Some of the components are: Conveyor belt, motor, pulley and idlers, rollers, pneumatic cylinder etc.

\section{Length of the belt, $\mathrm{L}=\mathrm{H} \times \mathrm{N} \times \pi$ in $\mathrm{m}$}

Where,

Vertical height of conveyor $(\mathrm{H})=350 \mathrm{~mm}=0.35 \mathrm{~m}$ Number of wayfers of belt $(\mathrm{N})=2$

$\mathrm{L}=2.19 \mathrm{~m}$

\section{Inclination, $\tan \beta=\underline{\text { Height of conveyor } \quad \text { in degrees }}$}

Distance between rollers

Where distance between two rollersis $2000 \mathrm{~mm}$

$\beta=9.92^{0}=10^{0}$

Belt Capacity, $c=$ Load bearing area of belt in $\mathrm{m}^{2} \times \mathrm{v} \times \rho$

Where,

Belt Speed $(\mathrm{v})=0.5 \mathrm{~m} / \mathrm{s}$ (desired speed)

Material Density $(\rho)=930 \mathrm{~kg} / \mathrm{m}^{3}$

Load bearing area of belt $=$ (length $\times$ breadth $)$ in $\mathrm{m}^{2}$

length of belt $=2.19 \mathrm{~m}$

breadth of belt $=0.9 \mathrm{~m}$

Load bearing area of belt $=1.971 \mathrm{~m}^{2}$

Belt Capacity, $\mathrm{c}=91.6515 \mathrm{~kg} / \mathrm{s}=330 \times 10^{3} \mathrm{~kg} / \mathrm{hr}$

Belt Width, $B \geq X a+200$

Where,

$\mathrm{X}$ : Longest diagonal of irregular lump, (300 mm)

a: maximum linear size of the representative lump (2.5)

$\mathrm{B} \geq 1150 \mathrm{~mm}$

Belt width is selected to be $1200 \mathrm{~mm}$ for our design.

Table -3: Diameter of roller

\begin{tabular}{|l|l|l|l|}
\hline Classification & $\begin{array}{l}\text { Diameter } \\
\text { (Inch) }\end{array}$ & $\begin{array}{l}\text { Belt Width } \\
\text { (Inch) }\end{array}$ & Description \\
\hline B4 & 4 & $18-48$ & Light duty \\
B5 & 5 & $18-48$ & Light Duty \\
\hline C4 & 4 & $18-60$ & Medium duty \\
C5 & 5 & $18-60$ & Medium duty \\
C6 & 6 & $24-60$ & Medium duty \\
\hline D5 & 5 & $24-72$ & Medium duty \\
D6 & 6 & $24-72$ & Medium duty \\
\hline E6 & 6 & $36-96$ & Heavy duty \\
E7 & 7 & $36-96$ & Heavy duty \\
\hline
\end{tabular}

From design data hand book based on belt width the diameter of roller is selected to be of C6 classification. i.e., $\mathrm{D}_{\text {roller }}=152.4 \mathrm{~mm}(6$ inch $)$

Total Belt length $=2 \times \mathrm{L}=4.38 \mathrm{~m}$

Power required by conveyor to produce lift, $\mathrm{P}_{\mathrm{L}}=\underline{\mathrm{c} \times \mathrm{H} \times 9.81}$ $3600 \times 1000$

$\mathrm{P}_{\mathrm{L}}=0.315 \mathrm{~kW}=0.32 \mathrm{~kW}$ $\mathrm{W}=$ weight of material + weight of belt, $\mathrm{kg} / \mathrm{m}$

where,

Weight of material, $\mathrm{Wm}=77 \mathrm{~kg} / \mathrm{m}$

Weight of belt $=10 \mathrm{~kg} / \mathrm{m}$

$\mathrm{W}=87 \mathrm{~kg} / \mathrm{m}$

Return side friction $=4 \mathrm{~F}_{\mathrm{e}} \times \mathrm{W} \times \mathrm{L} \times 9.81 \times 10^{-3}$

Where,

Equipment friction factor $(\mathrm{Fe})=0.0225$

Return side friction $=0.168 \mathrm{~N}$

Effective tension, $\mathrm{T}_{\mathrm{e}}=$ Total empty friction + Load friction + Load slope tension

Total empty friction $=\mathrm{F}_{\mathrm{e}} \times\left(\mathrm{L}+\mathrm{t}_{\mathrm{f}}\right) \times \mathrm{W} \times 9.81 \times 10^{-3}$

Load friction $=\mathrm{F}_{\mathrm{e}} \times\left(\mathrm{L}+\mathrm{t}_{\mathrm{f}}\right) \times(\mathrm{c} / 3600 \times \mathrm{v}) \times 9.81 \times 10^{-3}$

Load Slope tension $=\left(\mathrm{C} \times \mathrm{H} \times 9.81 \times 10^{-3}\right) / 3600 \times \mathrm{v}$

Where,

Terminal frictional co-efficient $\left(t_{\mathrm{f}}\right)=60$

Total empty friction $=1.19 \mathrm{kN}$

Load friction $=2.52 \mathrm{kN}$

Load Slope tension $=0.63 \mathrm{kN}$

Effective tension, $\mathrm{T}_{\mathrm{e}}=4.34 \mathrm{kN}$

Belt tension at Steady State

The belt of the conveyor system always undergo tensile load due to rotation of the motor, weight of the conveyed materials and due to the idlers. The belt tension must be proper range to avoid slippage between the drive pulley and the belt. Tension of belt at steady state is given by:

$$
\begin{gathered}
\mathrm{T}_{\mathrm{SS}}=1.37 \times \mathrm{f} \times \mathrm{L} \times \mathrm{g}\left[2 \times \mathrm{M}_{\mathrm{i}}+\left(2 \times \mathrm{M}_{\mathrm{b}}+\mathrm{M}_{\mathrm{m}}\right) \times \cos \beta\right]+\mathrm{H} \times \\
\mathrm{g} \times \mathrm{M}_{\mathrm{m}}
\end{gathered}
$$

Where,

$\mathrm{T}_{\mathrm{SS}}=$ Belt tension at steady state $(\mathrm{N})$

$\mathrm{f}=$ Coefficient of friction $(0.02)$

$\mathrm{g}=$ Acceleration due to gravity $\left(9.81 \mathrm{~m} / \mathrm{sec}^{2}\right)$

$\mathrm{M}_{\mathrm{i}}=$ Load due to the rollers $(200 \mathrm{~kg})$

$\mathrm{M}_{\mathrm{b}}=$ Load due to belt (20 kg total load of belt)

$\mathrm{M}_{\mathrm{m}}=$ Load due to conveyed materials $(168 \mathrm{~kg})$

$\beta=$ Inclination angle of the conveyor $\left(10^{\circ}\right)$

$\mathrm{H}=$ Vertical height of the conveyor $(0.35 \mathrm{~m})$

$\mathrm{T}_{\mathrm{SS}}=1.9 \mathrm{kN}$

Belt tension while starting

During the start of the conveyor system, the tension in the belt will be much higher than the steady state. The belt tension while starting is $\left(\mathrm{T}_{\mathrm{s}}\right)$

$$
\mathrm{T}_{\mathrm{s}}=\mathrm{T}_{\mathrm{SS}} \times \mathrm{k}_{\mathrm{s}} \text { in } \mathrm{kN}
$$


Where,

$\mathrm{k}_{\mathrm{s}}=$ Startup factor: 1.08

$\mathrm{T}_{\mathrm{s}}=2.052 \mathrm{kN}$

Unitary Maximum tension, $\mathrm{T}_{\mathrm{U}} \mathrm{Max}=\underline{\mathrm{Tss} \times 10}$ in N/mm

$\mathrm{T}_{\mathrm{U}} \operatorname{Max}=15.83 \mathrm{~N} / \mathrm{mm}$

Belt Power, $\mathrm{P}_{\mathrm{b}}=\mathrm{T}_{\mathrm{e}} \mathrm{x} \mathrm{v}$

$\mathrm{P}_{\mathrm{b}}=2.17 \mathrm{~kW}$

Effective pull, $F_{u}=\mu_{T} \times g\left(M_{m}+M_{B} / 2\right)+\mu_{R} \times g \times\left(M_{B} / 2\right.$ $\left.+\mathrm{M}_{\mathrm{i}}\right)$

Where,

$\mu_{\mathrm{T}}=$ Coefficient of friction with support rollers $(0.03$

$\mu_{R}=$ Coefficient of friction with skid plate $(0.33)$

$\mathrm{g}=$ Acceleration due to gravity $\left(9.8 \mathrm{~m} / \mathrm{s}^{2}\right)$

$\mathrm{M}_{\mathrm{m}}=$ Total load of conveyed materials $(168 \mathrm{~kg}$ )

$\mathrm{M}_{\mathrm{B}}=$ Mass of belt $(20$

$\mathrm{M}_{\mathrm{i}}=$ Mass of rollers $(200 \mathrm{~kg})$

$\mathrm{F}_{\mathrm{u}}=737.45 \mathrm{~N}$

Power at drive pulley, $\mathrm{P}_{\mathrm{p}}=\underline{\mathrm{F}}_{\underline{\underline{u}}} \underline{\underline{x}} \underline{\underline{v}}$ in $\mathrm{kW}$ 1000

$P_{p}=0.368 \mathrm{~kW}$

Minimum power of Motor $\left(\mathrm{P}_{\mathrm{Min}}\right)=\mathrm{Pp} / \eta \mathrm{kW}$

Considering a factor of safety of 2, power required to drive pulley is $0.737 \mathrm{~kW}$, efficiency of gear reduction $(\eta) 0.8$. So motor power $\mathrm{P}=0.92 \mathrm{~kW}=1.23 \mathrm{hp}$

$$
\text { Belt Breaking Strength, } B_{b s}={\underline{C_{l}}}_{\mathrm{C}_{V_{-}} \times P_{\underline{V}}} \text { in N }
$$

Where,

$\mathrm{C}_{\mathrm{r}}=$ Friction factor (15)

$\mathrm{C}_{\mathrm{V}}=$ Breaking strength loss factor $(0.75)$

$\mathrm{P}_{\mathrm{p}}=$ Power at drive pulley $(\mathrm{W})$

$\mathrm{V}=$ Belt speed $(0.5 \mathrm{~m} / \mathrm{s})$

$\mathrm{B}_{\mathrm{bs}}=14720 \mathrm{~N}=14.7 \mathrm{kN}$

Acceleration, $\mathrm{A}=\left(\mathrm{Ts}_{\mathrm{ss}}\right) / \mathrm{L} \times\left(2 \times \mathrm{M}_{\mathrm{i}}+2 \mathrm{M}_{\mathrm{B}}+\mathrm{M}_{\mathrm{m}}\right)$

$\mathrm{A}=1.02 \times 10^{-4} \mathrm{~m} / \mathrm{sec}^{2}$

Cycle time of conveyor $=\frac{2 \mathrm{~L}}{\mathrm{~V}}$

Cycle time of conveyor $=8.76 \mathrm{sec}$.

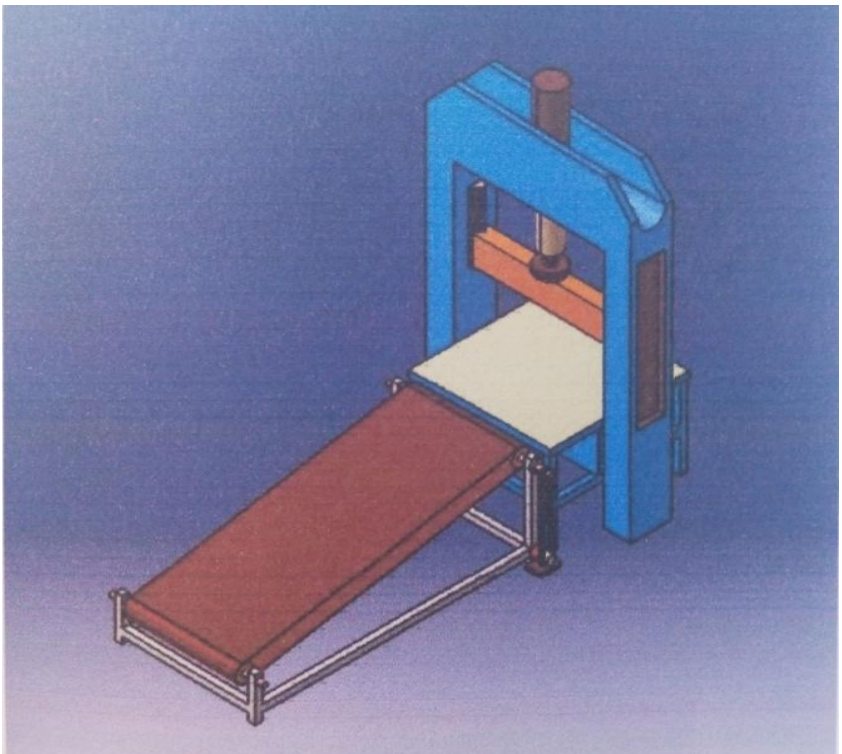

Fig -6: proposed conveyor system

Table -4: Design values for belt conveyor

\begin{tabular}{|c|c|c|}
\hline SI No & Parameter & Dimension \\
\hline 1 & Belt Length & $2.19 \mathrm{~m}$ \\
\hline 2 & Inclination & $10^{0}$ \\
\hline 3 & Belt Speed & $0.5 \mathrm{~m} / \mathrm{s}$ \\
\hline 4 & Belt Capacity & $300 \times 10^{3} \mathrm{~kg} / \mathrm{hr}$ \\
\hline 5 & Belt Width & $1200 \mathrm{~mm}$ \\
\hline 6 & Roller Diameter & 6 inches \\
\hline 7 & Total Belt Length & $4.38 \mathrm{~m}$ \\
\hline 8 & $\begin{array}{l}\text { Power Required to } \\
\text { produce Lift }\end{array}$ & $0.32 \mathrm{~kW}$ \\
\hline 9 & Return Side Friction & $0.168 \mathrm{~N}$ \\
\hline 10 & Total Empty Friction & $1.19 \mathrm{kN}$ \\
\hline 11 & Load Friction & $2.52 \mathrm{kN}$ \\
\hline 12 & Load Slope Tension & $0.63 \mathrm{kN}$ \\
\hline 13 & Effective Tension & $4.34 \mathrm{kN}$ \\
\hline 14 & $\begin{array}{lll}\begin{array}{l}\text { Steady } \\
\text { Tension }\end{array} & \text { State } & \text { Belt } \\
& & \end{array}$ & $1.9 \mathrm{kN}$ \\
\hline 15 & $\begin{array}{l}\text { Belt Tension while } \\
\text { Starting }\end{array}$ & $2.052 \mathrm{kN}$ \\
\hline 16 & $\begin{array}{l}\text { Unitary } \\
\text { Tension }\end{array}$ & $15.83 \mathrm{~N} / \mathrm{mm}$ \\
\hline 17 & Belt Power & $2.17 \mathrm{~kW}$ \\
\hline 18 & Effective Pull & $737.45 \mathrm{~N}$ \\
\hline 19 & Power at Drive Pulley & $0.368 \mathrm{~kW}$ \\
\hline 20 & $\begin{array}{ll}\text { Minimum } & \text { Motor } \\
\text { Power } & \\
\end{array}$ & $23 \mathrm{hp}$ \\
\hline 21 & $\begin{array}{ll}\text { Belt } & \text { Breaking } \\
\text { Strength } & \\
\end{array}$ & $14.7 \mathrm{kN}$ \\
\hline 22 & Acceleration & $1.02 \times 10^{-4} \mathrm{~m} / \mathrm{s}^{2}$ \\
\hline 23 & $\begin{array}{ll}\text { Cycle Time } & \text { of } \\
\text { Conveyor } & \end{array}$ & $8.76 \mathrm{~s}$ \\
\hline
\end{tabular}




\subsection{Modeling, Meshing and Analysis.}

The modeling of a required blade and blade holder are done by using the Unigraphix software (UG-NX 8.0) product of Siemens, initially the individual parts were modeled as per the dimensions. After completion of modeling of all drawings it was assembled together.

Parts modeled are shown in figures below

\section{Design 1}

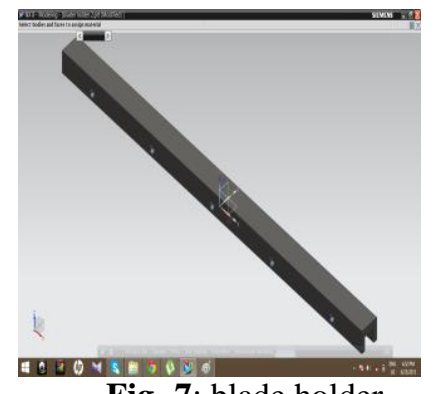

Fig -7: blade holder

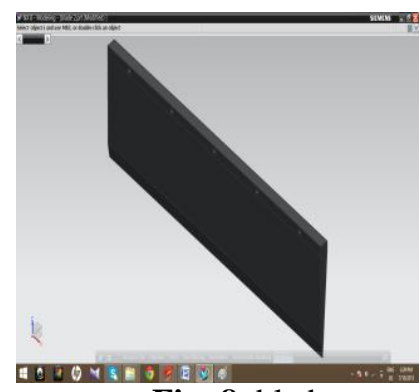

Fig -8: blade

The blade holder fits on the blade and they are assembled by using the hexagonal headed nut and bolt.

\section{Design 2}
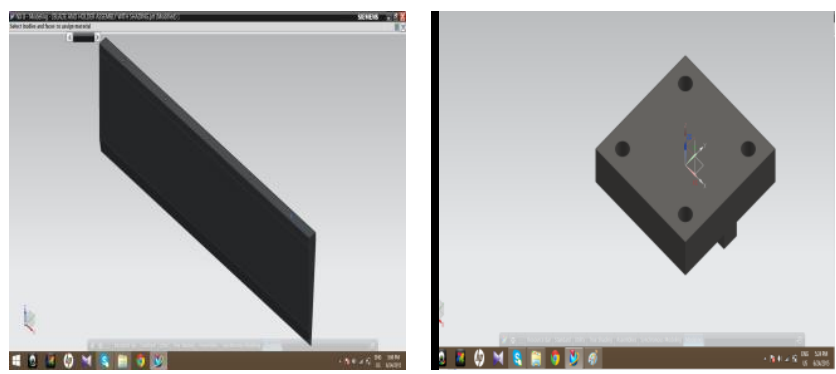

Fig -9: blade

Fig -10: blade holder center top

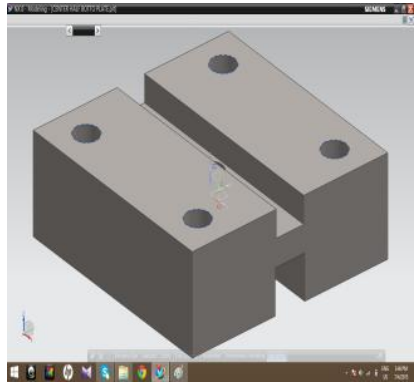

Fig -11: blade holder center Bottom

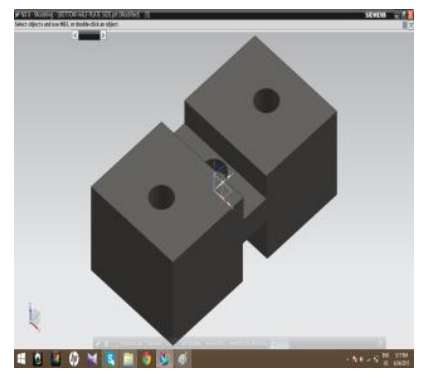

Fig -13: blade holder side bottom

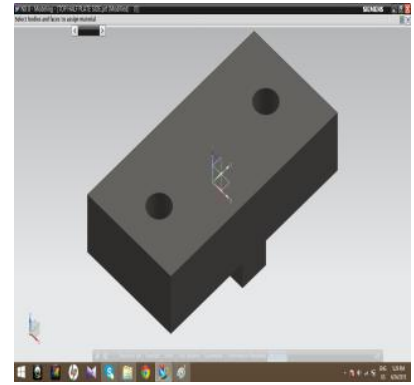

Fig -12: blade holder side top

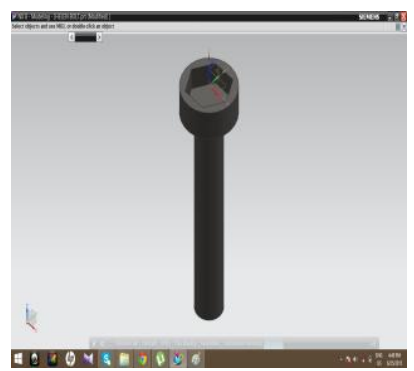

The top half blade holders are fixed to the ram, the blade holder bottom half fits on the blade and the threaded hole provided at the blade top matches the hole provided at the bottom half blade holder (both centre and side) the Helen bolt is used to fasten the blade to the bottom blade holder, and by using the hexagonal headed nut and bolt bottom half and top half are fastened. Assembly drawings of both models are shown in fig 2 and fig 3

Meshing is carried out by using the Hypermesh 11.0 As the model is more than $8 \mathrm{~mm}$ in thickness so the Hexamesh was carried out, meshing divides complex body into various smalldivisions with maintaining systematic interconnectivity between the parts which helps in analyzing process and helps in obtaining accurate results

The meshed model of the designs are shown in figure below

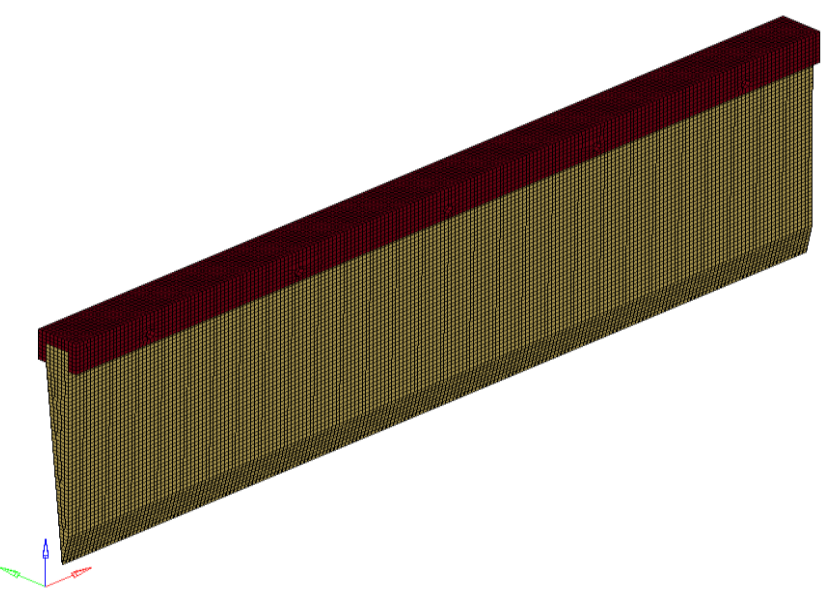

Fig -15: Mesh model of design 1

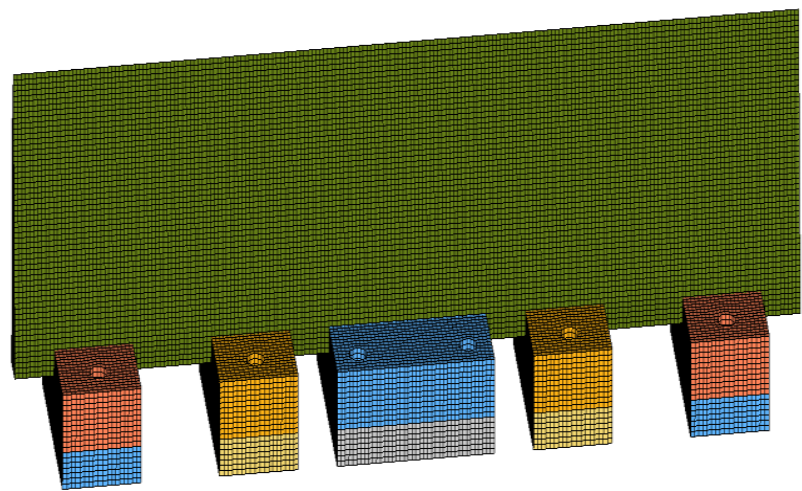

Fig -16: Mesh model of design 2

Analysis of the blade and holder designs were carried out using the Nastran pattern as the blade and blade holder are rigidly fixed to the ram so the static analysis is suitable for the case. The analysis comprises of finding out the stress and displacement analysis (deformation), the both models are made to act with an shear force $\left(350 \times 10^{3}\right)$ in $\mathrm{N}$. 
Displacement and stress analysis for design1

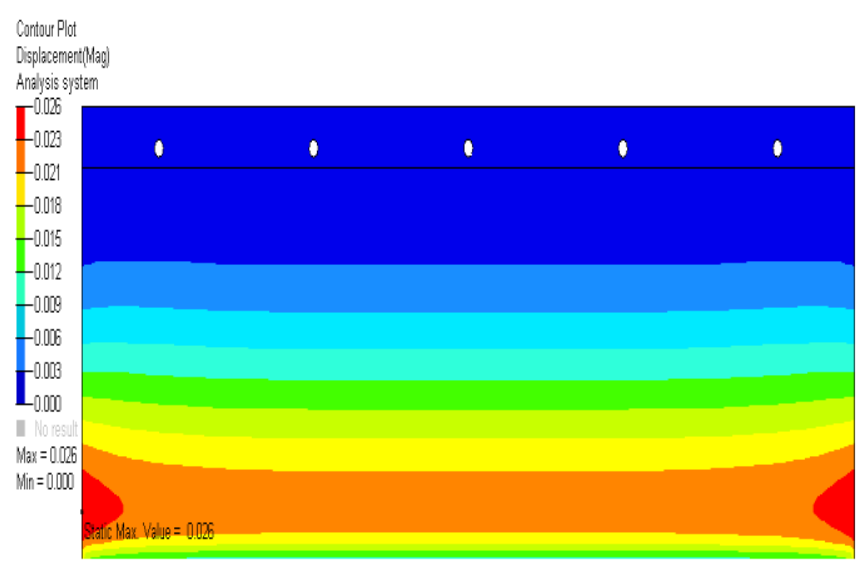

Fig -17: Displacement analysis of design 1

The results obtained shows the maximum displacement in the model is $0.026 \mathrm{~mm}$ and the design is safe to use.

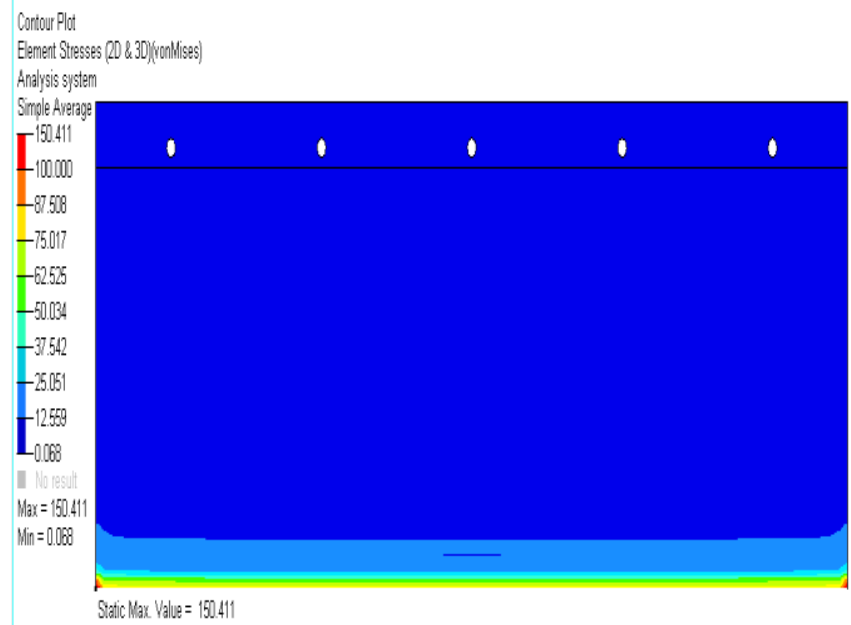

Fig -18: Stress analysis of design 1

The results obtained shows the maximum stress in the model is $152.41 \mathrm{~N} / \mathrm{mm}^{2}$ where as the allowable stress level is 960 $\mathrm{N} / \mathrm{mm}^{2}$ and the design is find safe to use.

Displacement and stress analysis for design 2

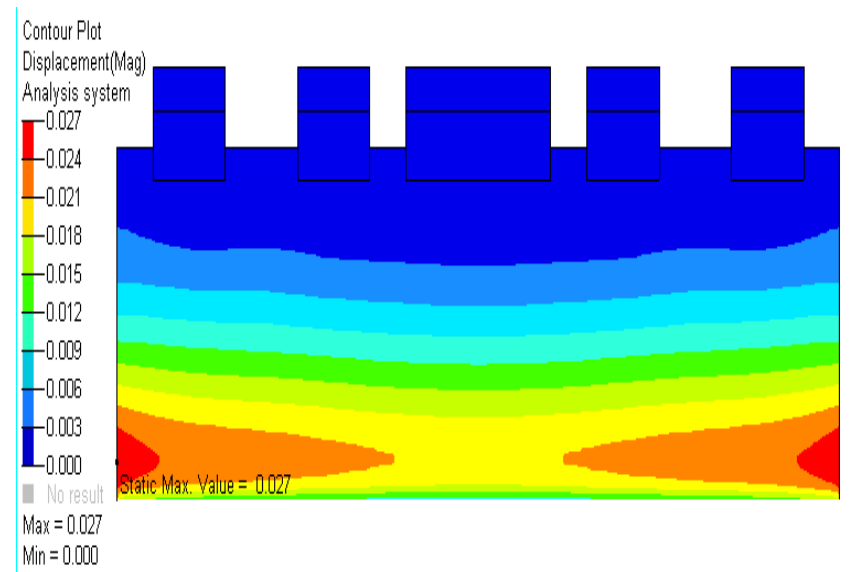

Fig -19: Displacement analysis of design 2
The results obtained shows the maximum displacement in the model is $0.027 \mathrm{~mm}$ and the design is safe to use

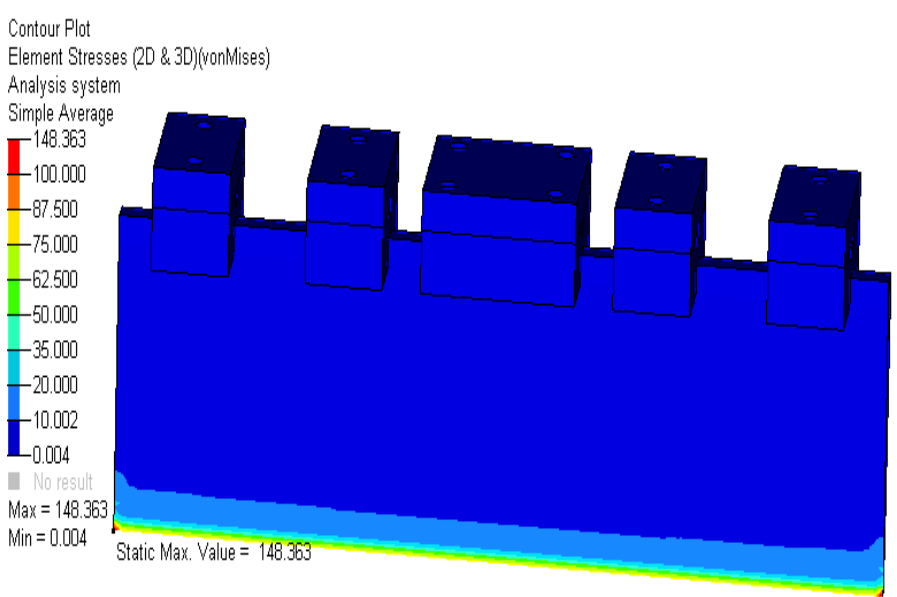

Fig -20: Stress analysis of design 2

The results obtained shows the maximum stress in the model is $148.363 \mathrm{~N} / \mathrm{mm}^{2}$ where as the allowable stress level is 960 $\mathrm{N} / \mathrm{mm}^{2}$ and the design is find safe to use.

\section{RESULTS AND CONCLUSION}

\subsection{Performance Comparison}

After the modification of the machine the results found were quite interesting the blade designed was successful in cutting four bales in a single stroke and the labour required for handling the process is increased from 3 to 4 till though the process is found more economical as show below.

Table -5: performance comparison

\begin{tabular}{|l|l|l|l|}
\hline \multicolumn{3}{|l|}{$\begin{array}{l}\text { Performance of bale cutting machine before and } \\
\text { after modification }\end{array}$} \\
\hline $\begin{array}{l}\text { Production } \\
\text { for 2890 } \\
\text { bales }\end{array}$ & $\begin{array}{l}\text { Before } \\
\text { modification }\end{array}$ & $\begin{array}{l}\text { After modification } \\
\text { Without } \\
\text { conveyor }\end{array}$ & $\begin{array}{l}\text { With } \\
\text { conveyor }\end{array}$ \\
\hline $\begin{array}{l}\text { Time } \\
\text { required in } \\
\text { hours }\end{array}$ & 24.08 & 6.82 & 5.61 \\
\hline
\end{tabular}

Table -6: specification of bale cutter before and after modification

\begin{tabular}{|l|l|l|}
\hline Make & Existing & Modified \\
\hline Cutting stroke & $500 \mathrm{~mm}$ & $500 \mathrm{~mm}$ \\
\hline Diameter of cylinder & $150 \mathrm{~mm}$ & $150 \mathrm{~mm}$ \\
\hline Cylinder pressure & $200 \mathrm{~kg} / \mathrm{sq} \mathrm{cm}$ & $210 \mathrm{~kg} / \mathrm{sp} \mathrm{cm}$ \\
\hline $\begin{array}{l}\text { Blade width/stock } \\
\text { thickness }\end{array}$ & $\begin{array}{l}400 \mathrm{~mm} / 150 \\
\mathrm{~mm}\end{array}$ & $\begin{array}{l}1000 \mathrm{~mm} / 280 \\
\mathrm{~mm}\end{array}$ \\
\hline Time of cutting stroke & $12 \mathrm{~seconds}$ & $12 \mathrm{sec}$ \\
\hline Motor power & $15 \mathrm{hp}$ & $21 \mathrm{hp}$ \\
\hline $\begin{array}{l}\text { Number of bales cut per } \\
\text { stroke }\end{array}$ & $1 \mathrm{no's}$ & $4 \mathrm{no's}$ \\
\hline Material handling time & $18 \mathrm{sec}$ & $16 \mathrm{sec}$ \\
\hline Stress on labour & More & Reduced \\
\hline Material handling & Manual & $\begin{array}{l}\text { Conveyor } \\
\text { system }\end{array}$ \\
\hline
\end{tabular}


Table -7: comparison of cost incurred to run machine per month

\begin{tabular}{|l|l|l|}
\hline \multicolumn{3}{|l|}{$\begin{array}{l}\text { Cost of running per month of bale cutting } \\
\text { machine before and after modification }\end{array}$} \\
\hline \multirow{2}{*}{$\begin{array}{l}\text { Before } \\
\text { modification }\end{array}$} & $\begin{array}{l}\text { After modification } \\
\text { Without } \\
\text { conveyor }\end{array}$ & $\begin{array}{l}\text { With } \\
\text { conveyor }\end{array}$ \\
\hline Rs.129500 & Rs.64280 & Rs.52500 \\
\hline
\end{tabular}

\subsection{Conclusion}

After modification that is., redesigning of the bale cutting machine resulted in savings of $70-80 \%$ in time, $50-65 \%$ of money, with achievement of $100 \%$ planned productivity. Whereas the original machine was giving about $90 \%$ productivity and increased expenditure further stress on the workers. And the overall modification cost (without conveyor) is Rs 116340 with payback period of 1.783 months, and the overall modification cost (with conveyor) is Rs 206340 and the payback period is 2.67 months.

Table -8: Overall performance of machine

\begin{tabular}{|c|c|c|c|}
\hline & $\begin{array}{l}\text { Time in } \\
\text { hours }\end{array}$ & $\begin{array}{l}\text { Productivity } \\
\text { in no's }\end{array}$ & $\begin{array}{l}\text { Money in } \\
\text { Rs. }\end{array}$ \\
\hline $\begin{array}{l}\text { Estimated } \\
\text { plan }\end{array}$ & 24.08 & 2890 & $1,29,500$ \\
\hline $\begin{array}{l}\text { Performance } \\
\text { achieved } \\
\text { bale cutting } \\
\text { machine }\end{array}$ & 21.25 & 2610 & $1,29,500$ \\
\hline $\begin{array}{l}\text { Performance } \\
\text { after } \\
\text { modification }\end{array}$ & $\begin{array}{l}6.82 \\
\text { without } \\
\text { conveyor } \\
(71.67 \% \\
\text { reduction) } \\
5.61 \\
\text { with } \\
\text { conveyor } \\
\text { ( } 76.70 \% \\
\text { reduction) }\end{array}$ & 2890 & $\begin{array}{l}64,280 \\
\text { without } \\
\text { conveyor } \\
(50,36 \% \\
\text { reduction) } \\
52500 \\
\text { with } \\
\text { conveyor } \\
\text { (59.45\% } \\
\text { reduction) }\end{array}$ \\
\hline
\end{tabular}

\section{REFERENCES}

[1]. IA. Daniyan *, A. O. Adeodu and O. M. Dada (2014) Design of a Material Handling Equipment: Belt Conveyor System for Crushed Limestone Using 3 roll Idlers.

[2]. Aniket A Jagtap1*, Shubham D Vaidya1, Akash R Samrutwar1, Rahul G Kamadil and Nikhil V Bhende1 (2015) research paper on design of material handling equipment;belt conveyor system for crushed biomass wood using v merge conveying system,

[3]. Design data hand book by Lingiah vol 1, vol 2.

[4]. Mahesh Todkar, NIT Warangal, ppt on rake angle on cutting tools

[5]. Rexroth Bosch Group Manual on Industrial HydraulicsHydraulic and Electronic Components, Product Range Information

[6]. Falcon tyres.com

[7]. Wisetools.com 